\title{
Comparison of two diagnostic techniques to determine the prevalence of Schistosoma mansoni infections in Cameroonian school children
}

\author{
${ }^{1}$ Sangue Soppa, N. P., ${ }^{1}$ Mekam Nkengni, S. M., ${ }^{1}$ Nguepnang, R. P., ${ }^{2}$ Vignoles, P., \\ ${ }^{3,4}$ Tchuem-Tchuenté, L. A., and ${ }^{1 *}$ Djuikwo Teukeng, F. F. \\ ${ }^{1}$ Faculty of Health Sciences, Campus of Banekane, Université des Montagnes, P. O. Box 208, \\ Bangangté, Cameroon \\ ${ }^{2}$ INSERM U 1094, Institute of Neuroepidemiology and Tropical Neurology, 2, rue du Docteur \\ Raymond Marcland, 87025 Limoges, France \\ ${ }^{3}$ Centre for Schistosomiasis and Parasitology, Texaco Omnisport, P. O. Box 7244, Yaoundé, \\ Cameroon \\ ${ }^{4}$ Laboratory of Parasitology and Ecology, Faculty of Sciences, University of Yaoundé I, Yaoundé, \\ Cameroon \\ *Correspondence to: ffnouboue@yahoo.fr
}

\begin{abstract}
:
Background: The Kato-Katz technique is recommended for diagnosis of Schistosoma mansoni infection by the World Health Organization. However, egg counts are subject to variability. The aim of this study is to determine the prevalence of S. mansoni infection in school children using two different techniques and to recommend the technique that should be routinely used in the diagnosis of this infection.

Methodology: Field investigations on faecal samples from 299 Cameroonian school children were carried out in 2016 to compare the effectiveness of the Kato-Katz and Formalin-ether techniques in diagnosis of S. mansoni infections.

Results: Schistosome eggs were detected in $37(12.3 \%)$ samples with the Kato-Katz technique and $61(20.4 \%)$ samples with the Formalin-ether technique. The difference between the prevalence observed for the two techniques was significant in males and age group $10-12$ years $(p<0.5)$.

Conclusion: The Formalin-ether technique was more sensitive than the Kato-Katz method for detecting S. mansoni eggs in faecal matter. Despite its cost, the Formalin-ether technique can be routinely used in the laboratory for epidemiological studies of intestinal schistosomiasis
\end{abstract}

Key words: Formalin-ether, Kato-Katz Schistosoma mansoni, school children

Received January 9, 2019; Revised March 14, 2019; Accepted March 28, 2019

Copyright 2019 AJCEM Open Access. This article is licensed and distributed under the terms of the Creative Commons Attrition 4.0 International License (http://creativecommmons.org/licenses/by/4.0), which permits unrestricted use, distribution and reproduction in any medium, provided credit is given to the original author(s) and the source.

\section{Comparaison de deux techniques de diagnostic pour déterminer la prévalence d'infections à Schistosoma mansoni chez des écoliers camerounais}

\footnotetext{
${ }^{1}$ Sangue Soppa, N. P., ${ }^{1}$ Mekam Nkengni, S. M., ${ }^{1}$ Nguepnang, R. P., ${ }^{2}$ Vignoles, P.,
} ${ }^{3,4}$ Tchuem-Tchuenté, L. A., and ${ }^{1 *}$ Djuikwo Teukeng, F. F. 


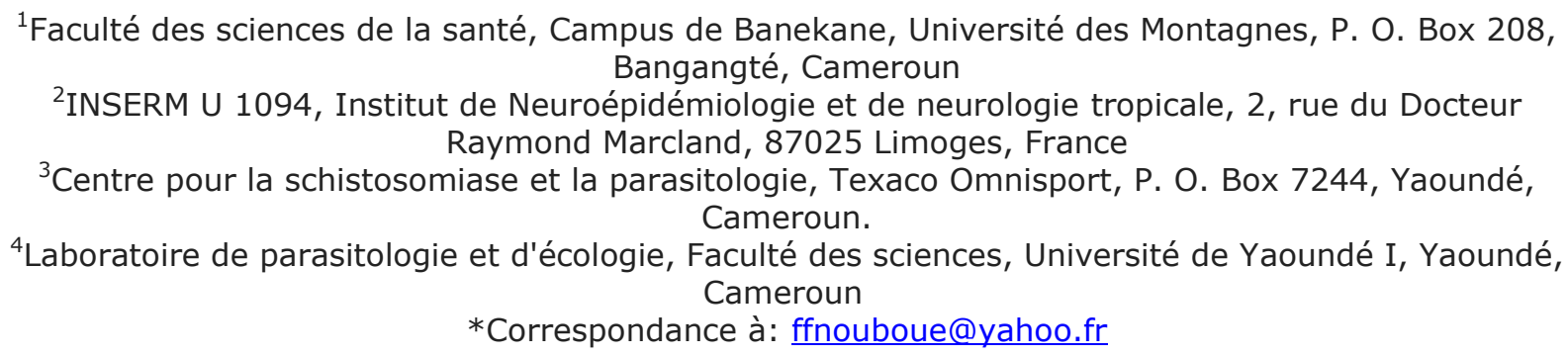

\section{Résumé:}

Contexte: La méthode Kato-Katz est recommandée par l'Organisation mondiale de la santé pour le diagnostic de l'infection à Schistosoma mansoni. Cependant, le nombre d'œufs est sujet à une variabilité. Le but de cette étude est de déterminer la prévalence de l'infection à S. mansoni chez les écoliers en utilisant deux techniques différentes et de recommander la technique à utiliser systématiquement pour le diagnostic de cette infection.

Méthodologie: Des enquêtes sur le terrain sur des échantillons de selles provenant de 299 écoliers camerounais ont été menées en 2016 pour comparer l'efficacité des techniques de KatoKatz et au formol-éther dans le diagnostic des infections à S. mansoni.

Résultats: Des œufs de schistosomes ont été détectés dans 37 échantillons (12,3\%) avec la technique de Kato-Katz et 61 échantillons (20,4\%) avec la technique au formol-éther. La différence entre la prévalence observée pour les deux techniques était significative chez les hommes et chez les $10-12$ ans $(p<0,5)$.

Conclusion: La technique au formol-éther était plus sensible que la méthode de Kato-Katz pour détecter les œufs de S. mansoni dans les matières fécales. En dépit de son coût, la technique formol-éther peut être utilisée systématiquement en laboratoire pour des études épidémiologiques sur la schistosomiase intestinale.

Mots-clés: formol-éther, Kato-Katz, Schistosoma mansoni, écoliers

\section{Introduction:}

Human schistosomiasis is a disease transmitted by freshwater snails and caused by blood flukes of the genus Schistosoma. This parasitic infection is widespread in tropical and subtropical areas and has been reported in 78 countries (1-2). About 218 million people needed preventive treatment in 2015, however, this preventive chemotherapy is only required in 52 countries with moderate to high endemicity (3). The prevalence of schistosomiasis is still high in sub-Saharan Africa, as approximately 120 million individuals manifest symptoms of schistosomiasis (4). The main burden of this disease in subSaharan Africa is usually attributed to two species: Schistosoma mansoni and Schistosoma haematobium, which are designated as the major human schistosomes (5).

In Cameroon, intestinal schistosomiasis is endemic in the North and far North of the country (6) and more localized in the Southern part (7-9). A large-scale survey performed on 12,594 school children revealed that $S$. mansoni was the most prevalent schistosome species in the regions of Centre, East and West (9). Infected children were found in 60 of 244 schools investigated, with an average prevalence of $5.5 \%$ and a range of $0 \%$ to $66.3 \%$ in the three regions. In the regions of Littoral, NorthWest, South and South-West regions, the prevalence of $S$. mansoni infection among 4,130 school-aged children was lower, with an average prevalence of $3 \%$ and a range of $0 \%$ to $86 \%$ (10).

Stool examination is the main method for the diagnosis of suspected $S$. mansoni infections and the Kato-Katz technique is the most commonly used (11-12). This technique is recommended for surveillance and epidemiological field surveys of soil-transmitted helminthic diseases because of its ease of use in the field and the relatively low cost (13). In addition, it provides satisfactory results in case of mass investigations (13). However, the amount of faecal matter (20-50 mg) used for diagnosis is low, which causes a great variability in the number of eggs identified (14). On the other hand, the formalin-ether technique is time consuming and requires several 
materials. It is however recommended as the best overall method for concentrating parasite eggs in faeces (15). Reliable diagnosis of intestinal schistosomiasis requires a rapid, cheap, and less laborious method as well as water-based techniques.

As the treatment of $S$. mansoni is dependent on the presence of eggs in faeces, the aim of the present study is to evaluate the effectiveness of two methods used to determine the prevalence of this disease. The study was conducted among school children in Penja, Cameroon, because Penja is known for its high endemicity of intestinal schistosomiasis (10).

\section{Methodology:}

The Penja municipality is located in the Department of Moungo and the region of Littoral. It covers the territory of the district of Njombe-Penja (arrondissement). Its surface area is $260 \mathrm{~km}^{2}$. The municipality had 36,287 inhabitants at the 2011 census. Its tropical climate and volcanic soil are at the origin of many ponds and small rivers which are regularly frequented by the population.

Faecal samples were collected in April 2016 from 299 children aged 4 to 16 years in three randomly selected schools in the town of Penja. Children were eligible if their parents or guardians gave written consent for the study and children have not received antihelminthic drugs prior to the time of stool collection. Each child was given an identification number and children were treated by local doctors if $S$. mansoni eggs were detected in their faeces.

In each school, faecal specimens were collected in the morning, placed in $60 \mathrm{~mL}$ screw-cap vials and transported in a portable cooler to the Laboratory at the Université des Montagnes for examination on the same day. The consistency and colour of each sample were first noted before subjecting them to the two diagnostic techniques. The first technique was the Kato-Katz technique (16). Briefly, $3 \mathrm{~g}$ of faeces were pressed through a sieve and 20 to $50 \mathrm{mg}$ of sieved materials was transferred to a slide. A piece of cellophane soaked in glycerin was placed on these materials. Glycerin eliminates faecal debris, allowing eggs to be seen and counted $45 \mathrm{~min}$ or more after preparation. The other technique was the Ritchie's formalin-ether technique (16). About $1 \mathrm{~g}$ of faeces was emulsified in a solution of formalin and water. The suspension was sieved and ether was then added. After centrifugation of the mixed suspension, the sediment was examined for coccidian oocysts and helminth eggs and/or larvae.

Differences between the prevalence obtained with the two techniques, and the relationship between prevalence, gender and age group of the children were compared using Fisher's exact test, with $p$ value less than 0.05 considered significant. The children were stratified into four age groups; < 7 years, 7-9 years, $10-12$ years, and $>12$ years. All analyses were performed using software R 3.3.0 (17).

\section{Results:}

Table 1 shows the distribution of the school children in relation to gender. Of the 299 faecal samples collected, 90 $(30.1 \%)$ were diarrheic in consistency while 209 were formed stool. One hundred and ten of the formed stool $(36.7 \%)$ were brown in colour while 99 $(33.1 \%)$ had blood stain.

Table 2 shows the prevalence of S. mansoni in relation to gender and age group of the children. Of the 299 children, schistosome eggs were recovered in 37 faecal samples (12.3\%) with the Kato-Katz technique and $61(20.4 \%)$ with the formol-ether technique. The difference between these techniques was significant $(p<0.05)$. The Formalin-ether technique detected more eggs in the males which was significantly more than the values from the females, and also in children aged $10-12$ years than from children in other age groups $(p<0.05)$. 
Table 1: Distribution of schoolchildren in relation to gender in Penja, Cameroon

\begin{tabular}{cccc}
\hline School & \multicolumn{2}{c}{ Gender } & Total \\
& Male & Female & \\
$\begin{array}{c}\text { Public primary } \\
\text { school 1 }\end{array}$ & 45 & 41 & 86 \\
$\begin{array}{c}\text { Public primary } \\
\text { school 2 }\end{array}$ & 85 & 71 & 156 \\
$\begin{array}{c}\text { Bilingual public } \\
\text { School }\end{array}$ & 35 & 22 & 57 \\
$\quad$ Total & 165 & 134 & 299 \\
\hline
\end{tabular}

Table 2: Prevalence of Schistosoma mansoni infection in schoolchildren at Penja, Cameroon

\begin{tabular}{llll}
\hline Gender and age group & $\begin{array}{l}\text { Number of } \\
\text { children }\end{array}$ & $\begin{array}{l}\text { Number of positive faecal samples with } \\
\text { Schistosoma mansoni (prevalence in \%) } \\
\text { Kato-Katz } \\
\text { technique }\end{array}$ & $\begin{array}{l}\text { Formalin-ether } \\
\text { technique }\end{array}$ \\
$\begin{array}{l}\text { Gender of children } \\
\text { Male }\end{array}$ & 165 & $19(11.5)$ & $34(20.6)^{*}$ \\
$\quad \begin{array}{l}\text { Female } \\
\text { Age group (years) }\end{array}$ & 134 & $18(13.4)$ & $27(20.1)$ \\
$4-6$ & 20 & $2(10.0)$ & $4(20.0)$ \\
$7-9$ & 75 & $11(14.6)$ & $19(25.3)$ \\
$10-12$ & 166 & $19(11.4)$ & $31(18.6)^{*}$ \\
$>12$ & 38 & $5(13.1)$ & $7(18.4)$ \\
Total & 299 & $37(12.3)$ & $61(20.4)^{*}$ \\
\hline${ }^{*} p<0.05$ & & &
\end{tabular}

\section{Discussion:}

Contradictory results have been reported in the literature on the effectiveness of Kato-Katz and Formolether techniques in the detection of gastrointestinal parasites in faeces. Some authors have noted that the KatoKatz technique was better and significantly more sensitive than the other method (18-19) while others have reported that the Formol-ether technique had a better sensitivity than the KatoKatz method (20-21). According to Knight et al., (22), the concentration of eggs in the faeces enabled the detection of more patients infected with $S$. mansoni when the Formol-ether technique was used. The results reported in the present study are consistent with the reports of these last authors because $20 \%$ of children infected with S. mansoni were detected with the Formalin-ether technique (compared to $12 \%$ with the other method).

Although the Formol-ether technique is more expensive and labour intensive to perform than the Kato-Katz technique, its current use in parasitology laboratory would provide better results in the diagnosis of gastrointestinal infections. Although there was significant difference in the prevalence of $S$. mansoni infections detected by the two techniques among the male children in our study, other authors did not find clear difference in prevalence with respect to gender (23-24). The possible explanation for the difference observed in our study may be related to size and composition of our samples. Conversely, the difference in prevalence according to age group of children is consistent with reports of other authors (23-24).

In conclusion, the Formol-ether technique was clearly more sensitive than the Kato-Katz method for detecting $S$. mansoni eggs in faeces in this study. Despite its cost, this technique is recommended for routine use in the laboratory for epidemiological studies of intestinal schistosomiasis.

\section{Acknowledgements:}

The study was approved by the National Ethics Committee of Cameroon (Number/2016/079/UdM/PR/CAB/CIE), 
Ministry of Public Health and Ministry of Basic Education. Parasitological surveys were conducted in schools with the approval of local administrative authorities, school inspectors, directors and teachers. Information about the national programme for the control of schistosomiasis and the objectives of the study were explained to schoolchildren and their parents or guardians. The authors are grateful to all children and their parents or guardians for their excellent cooperation.

\section{Competing interest:}

\section{No competing interest is declared}

\section{References:}

1. Gryseels, B., Polman, K., Clerinx, J., and Kestens, L. Human schistosomiasis. Lancet. 2006; 368 (9541): 1106-1118

2. Steinmann, P., Keiser, J., Bos, R., Tanner, M., and Utzinger, J. Schistosomiasis and water resources development: systematic review, meta-analysis, and estimates of people at risk. Lancet Infect Dis. 2006; 6(7): 411-425

3. World Health Organization. Schistosomiasis. 2017. Available: www.who.int/mediacentre/ (accessed 16 February 2017)

4. Adenowo, A. F., Oyinloye, B. E., Ogunyinka, B. I., and Kappo, A. P. Impact of human schistosomiasis in sub-Saharan Africa. Braz J Infect Dis. 2015; 19 (2): 196-205

5. Utzinger, J., Raso, C., Brooker, S., de Savigny, D., Tanner, M., Ørnbjerg, N., Singer, B. H., and N'Goran, E. K. Schistosomiasis and neglected tropical diseases: towards integrated and sustainable control and a word of caution. Parasitology. 2009; 136 (13): 1859-1874

6. Doumenge, J. P., Mott, K. E., Cheung, C., Villenave, D., Chapuis, O., Perrin, M. F., and Reaud-Thomas, G. Atlas de la répartition mondiale des schistosomiases. Presses Universitaires, Bordeaux, 1987

7. Ratard, R. C., Kouemeni, L. E., Bessala, M. M., Ndamkou, C. N., Greer, G. J., Spilsbury, J., and Cline, B. L. Human schistosomiasis in Cameroon. I. Distribution of schistosomiasis. Am J Trop Med Hyg. 1990; 42 (6): 561-572

8. Njiokou, F., Onguene, A. R., TchuemTchuenté, L. A., and Kenmogne, A. 2004. Schistosomose urbaine au Cameroun : étude longitudinale de la transmission dans un nouveau site d'extension du foyer de schistosomose intestinale de Mélen, Yaoundé. Bull Soc Pathol Exot. 2004; 97 (1): 37-40

9. Tchuem-Tchuenté, L. A., Kamwa Ngassam, R. I., Sumo, L., et al. Mapping of schistosomiasis and soil-transmitted helminthiasis in the regions of Centre, East and West Cameroon. PLoS Negl Trop Dis. 2012; 6 (3): e1553

10. Tchuem-Tchuenté, L. A., Dongmo Noumedem, C., Ngassam, P., Kenfack, C. M., Gipwe, N. F., Dankoni, E., Tarini, A., and Zhang, Y. Mapping of schistosomiasis and soil-transmitted helminthiasis in the regions of Littoral, Northwest, South and South-west Cameroon and recommendations for treatment. BMC Infect Dis. 2013; 13 (13): 602

11. Goodman, D., Haji, H. J., Bickle, Q. D., Stoltzfus, R. J., Tielsch, J. M., Ramsan, M., Savioli, L., and Albonico, M. A comparison of methods for detecting the eggs of Ascaris, Trichuris and hookworm in infant stool and the epidemiology of infection in Zanzibar infants. Am J Trop Med Hyg. 2007; 76 (4): 725-731

12. Utzinger, J., Rinaldi, L., Lohourignon, L. K., Rohner, F., Zimmermann, M. B., Tschannen, A. B., N'Goran, E. K., and Cringoli, G. FLOTAC: a new sensitive technique for the diagnosis of hookworm infections in humans. Trans $\mathrm{R}$ Soc Trop Med Hyg. 2008; 102 (1): 84-90

13. World Health Organization. Bench aids for the diagnosis of intestinal parasites. World Health Organization, Geneva, 1994

14. Kongs, A., Marks, G., Verlé, P., and Van der Stuyft, P. The unreliability of the Kato-Katz technique limits its usefulness for evaluating S. mansoni infections. Trop Med Int Health. $2001 ; 6$ (3): 163-169

15. Cheesbrough M. Techniques used to identify parasites. Medical laboratory manual for tropical countries, Vol. I. ButterworthHeinemann Ltd., Oxford, 1991; 178-197

16. World Health Organization. The control of schistosomiasis. Second report of the WHO expert committee. World Health Organization Technical Report Series, no. 830. WHO, Geneva, 1993

17. R Core Team. R: a language and environment for statistical computing. 2016. R Foundation for Statistical Computing, Vienna, Austria. Available at: https://www.R-project.org (accessed on 17 February 2017)

18. Endris, M., Tekeste, Z., Lemma, W., and Kassu, A. Comparison of the Kato-Katz, wet mount, and formol-ether concentration diagnostic techniques for intestinal helminth infections in Ethiopia. Int. Sch. Res. Notices: Parasitol. 2013; 180439: 1-5

19. Qian, M. B., Yan, P., Yang, Y. C., Liang, H., Jiang, Z. H., Li, W., Utzinger, J., Zhou, X. N., and Keiser, J. Accuracy of the Kato-Katz method and formalin-ether concentration technique for the diagnosis of Clonorchis sinensis, and implication for assessing drug effectiveness. Parasit Vectors. 2013, 6: 314

20. Oguoma, V., and Ekwunife, C. The need for a better method: comparison of direct smear and formol-ether concentration techniques in diagnosing intestinal parasites. Internet $\mathrm{J}$ Trop Med. 2006; 3 (2): 1-6

21. Taye S. Comparison of Kato-Katz and formolether concentration methods for the diagnosis of intestinal helminthic infections among school children of Wonji Shoa Town, Eastern Ethiopia: A school based cross-sectional study. Am J Health Res. 2014; 2 (5): 271-274

22. Knight, W. B., Hiatt, R. A., Cline, B. L., and Ritchie, L. S. A modification of the formolether concentration technique for increased sensitivity in detecting Schistosoma mansoni eggs. Am J Trop Med Hyg. 1976; 25(6): 818823 
23. Ruganuza, D. M., Mazigo, H. D., Waihenya, R., Morona, D., and Mkoji, G. M. Schistosoma mansoni among pre-school children in Musozi village, Ukerewe Island, North-western Tanzania: prevalence and associated risk factors. Parasit Vectors. 2015; 8: 377
24. Alemu A., Tegegne Y., Damte D., Melku M. Schistosoma mansoni and soil-transmitted helminths among preschool-aged children in Chuahit, Dembia district, Northwest Ethiopia: prevalence, intensity of infection and associated risk factors. BMC Publ Health. 2016; 16: 422 